\title{
Experiments on explosive interaction of molten kimberlite with injected water
}

\author{
Kurszlaukis, S. ${ }^{1,2}$, Lorenz, V. ${ }^{1}$, Zimanowski, B. ${ }^{1}$, and Büttner, R. ${ }^{1}$ \\ 1. Physikalisch Vulkanologisches Labor, Institut für Geologie, Universität Würzburg, Pleicherwall 1, D-97070 \\ Würzburg, Germany \\ 2. now at Anglo American Research Laboratories (PTY) Ltd., P.O.Box 106, Crown Mines, 2025 South Africa
}

Kimberlite magma intruded continental cratonic and pericratonic as well as overlying rocks in dykes (and associated sills) and consolidated to form the igneous subvolcanic/hypabbyssal rock kimberlite. Kimberlite dykes in upper crustal levels (basement and sedimentary/volcanic cover) have an ordinary thickness of between several $\mathrm{cm}$ and several $\mathrm{m}$ and even $0.5-3 \mathrm{~km}$ below the Earth's surface may extend horizontally for up to several tens of $\mathrm{km}$. Very localized, but frequently associated with near-surface emplacement of dykes, kimberlite magma fragmented and formed kimberlite maar-diatreme volcanoes. Such dykes and maar-diatreme volcanoes usually occur in clusters and can be looked at as near surface features of a kimberlite volcanic field. Owing to the fact that kimberlite volcanic activity occurred from Precambrian until early Tertiary time, no original volcanic deposits survived erosion, neither from the kimberlite dykes nor from the kimberlite maar-diatreme volcanoes - with the possible exception of Kasami in the Kenieba Field in Mali and at Igwisi in Tanzania (Nixon, 1995). Thus the volcanoes fed directly by dykes, i.e. scoria cones and lava flows, may-be even small shield volcanoes, and the tephra rings surrounding kimberlite maars unfortunately have been eroded.

Formation of the kimberlite maar-diatreme volcanoes is due to intensive fragmentation of the kimberlite magma and of most of those country rocks which originally occupied the space of the diatreme. In models on the formation of kimberlite pipes, fragmentation of the kimberlite magma is assumed to have been the result either of explosive exolution of volatile phases (Clement, 1982; Clement and Reid, 1989), of explosive interaction of kimberlite magma with groundwater (Lorenz, 1975, 1998; Lorenz et al., 1994; Nixon, 1995), or of a combination of these magmatic and phreatomagmatic processes. Whereas it is increasingly accepted that maars and diatremes of magmas of any other composition, i.e. acid to basic, ultrabasic and ultramafic, as well as carbonatitic, are phreatomagmatic in origin, the dispute on the origin of kimberlite pipes is still continuing.

Any model on the origin of kimberlite pipes must account for the following aspects typical for these pipes: the general lack of vesicles in the juvenile kimberlite clasts; many kimberlite clasts are spherical in shape owing to the action of surface tension; high percentage of country rock clasts requiring explosive crushing processes; occurrence of country rock breccias in the root zones; emplacement of the diatreme rocks at low temperatures; serpentinisation of the kimberlite clasts and matrix through the action of groundwater; late high-level non-explosive intrusive dykes and plugs within kimberlite diatremes. Furthermore, in many kimberlite pipes the occurrence of thinly bedded primary pyroclastic deposits points to a multiple eruptive activity during emplacement of the pipes.

In order to test the potential of kimberlite melt for explosive phreatomagmatic eruptions hypabbyssal kimberlite from the central plug from the Hanaus 2 diatreme of the Gibeon Kimberlite Province in southern Namibia was remelted and water was injected to induce an explosive interaction. These experiments were performed in the TEE-II Lab at Würzburg (Zimanowski et al., 1997a). In Würzburg and previously in the TEE-Haus at the IKE Stuttgart allogether more than 1000 experiments were successfully performed on the explosive interaction (MFCI) between molten fuels of diverse compositions and the coolant water: Metal melts: Lead, Copper, Tin, Gallium, Iron, Iron Oxyde; Salt $(\mathrm{NaCl})$, Carbonate $\left(\mathrm{Na}_{2} \mathrm{CO}_{3}, \mathrm{~K}_{2} \mathrm{CO}_{3}\right)$ and a simplified Lengaite composition, and finally diverse silicate rocks: basaltic andesite, tholeiite, olivine tholeeite, basanite, nephelinite, and olivine melilitite. Most of the experiments were performed using olivine melilitite, because of two reasons: 1. this composition is of general relevance for basic to ultrabasic magmas. 2. its rheological properties allow the realization of a 
wide range of hydrodynamic contact conditions (magma/water) on a relatively small experimental scale.

Our experiments were performed in inductively heated crucibles $(5$ to $10 \mathrm{~cm}$ wide, 7 to $12 \mathrm{~cm}$ deep) within which the melts were prepared. Up to $50 \mathrm{ml}$ of purified water at room temperature was injected into the respective melt at injection velocities up to $20 \mathrm{~m} / \mathrm{s}$ (Zimanowski et al., 1997b). Consequently thermal explosions ocurred, either spontaneously or initiated by the application of a triggering pressure pulse. The explosions were monitored using high resolution measurement techniques. The experimentally produced "pyroclasts" were sampled and evaluated in respect to their modes of formation.

After 15 years of experimental studies the thermo-hydraulic explosion model was formulated (Büttner and Zimanowski, 1998), explaining the physical observations as follows: Phase 1, hydrodynamic mixing of water and melt under stable vapour-film boiling conditions leading to explosive premixes of $\mathrm{cm}$ to $\mathrm{dm}$ size water domains with wavy surfaces dispersed in excess melt. Phase 2, induction and propagation of a rapid breakdown of the insulating vapour films leading to the "direct contact" of both incompressible liquids, and thus to a thermal and mechanical coupling. Phase 3, melt fragmentation, escalative heat transfer, and superheating of water in a positive feedback loop leading to the emission of high energy explosion shock waves. Phase 4, expansion and decoupling of the system by quantitative vaporization of the water leading to the ejection ("eruption") of the system and to further fragmentation of the melt. Only about $10 \%$ of the total kinetic energy was released during Phase 4 , whereas nearly $90 \%$ was emitted during Phase 3 in the form of shock waves and seismic energy.

The kimberlite used in the experiments is derived from the central plug in Hanaus 2 diatreme (Kurszlaukis et al., 1998a). The non-vesicular plug has a diameter of about $15 \mathrm{~m}$ and, at its northern margin, shows well developed vertically oriented flow banding, displayed by zones of larger and smaller altered olivines. It is from this margin that the xenolith-free samples were taken. The plug was emplaced at a depth inside the diatreme in a non-explosive fashion near the basal level of the Karoo sediments which unconformably overly the Cambrian Nama shales, i.e. the plug is exposed at a depth of about $400 \mathrm{~m}$ below the original surface of Karoo sediments at the time of the diatreme emplacement. If the plug reached the crater floor and formed a scoria cone or lava lake inside the maar crater of Hanaus 2 is unknown of course.

For the experiments the kimberlite was granulated and melted $(130 \mathrm{ml})$ inside a $\mathrm{ZrO}_{2}-\mathrm{Mo}_{0}$ crucible at temperatures of $1600^{\circ} \mathrm{C}$ (Kurszlaukis et al., 1998b). Durning the process of melting no decomposition and only minor degassing was observed and a low viscosity melt (< 1 Pas) was obtained. A sample taken from this melt and quenched in air displayed some vesicles, probably due to liberation of $\mathrm{CO}_{2}$ and $\mathrm{H}_{2} \mathrm{O}$ from carbonate and hydrate phases. The usual procedure then was followed with injection of $15 \mathrm{ml}$ of water (at $4.2 \mathrm{~m} / \mathrm{s}$ ) at a depth of $6 \mathrm{~cm}$ below the melt surface and application of a low energy trigger signal $(<10 \mathrm{~J})$. In each experimental run a very strong explosion occurred, releasing kintetic energy of up to $22000 \mathrm{~J}$. The strongest explosions even destroyed the crucibles, thus formation of "country rock clasts" occurred.

Further experiments with another sample from the same locality had to be run at higher temperature. During heating of this material some decomposition was observed. This effect may be explained by an inhomogeneous composition of the plug.

When a sample from a xenolith-bearing kimberlite from Wesselton Pipe, South Africa, was tested, it did not even melt but dissociated only.

Implications of the experiments are: 1. In principle magmatic kimberlite can be melted at atmospheric conditions. 2. In explosion experiments the kimberlite proved to be even more explosive than the previously used remelted volcanic rocks. 3. The explosions also support the model of formation of kimberlite diatremes by phreatomagmatic explosions under suitable hydrogeological conditions. 4. The shock waves generated by the thermo-hydraulic explosions have the quality to be the cause for the fragmentation of large amounts of country-rocks which occur in diatremes. 5. The space where kimberlite magma and water interact explosively will be 
the transition of the kimberlite dyke to the diatreme. The final site of explosions will be preserved as the root zone of the diatreme (Lorenz and Kurszlaukis, 1997). 6. The very fine angular fragments which transferred their heat into the water are most unstable and will alter most easily during influx of groundwater into the diatreme, thus they cannot be recognized anymore.

Outlook: For a systematic approach a larger series of experiments has to be performed on explosive interaction of kimberlite melt with water in order to study the many different aspects of these explosions and their similarities with and differences to explosions of rather similar rock melts such as from olivine melilitite and nephelinite. Kimberlites from different provenance should be investigated. In addition kimberlites which decompose during heating should be analyzed in order to find out what was their original composition.

\section{References}

Büttner, R., and Zimanowski, B., 1998, On the physics of thermo-hydraulic explosion: Phys. Rev. E, in press.

Clement, C.R., 1982, A comparative geological study of some major kimberlite pipes in the Northern Cape and Orange Free State: Unpubl. Ph. D. Thesis, Univ. Cape Town, South Africa, 2 Vol., p. 1-432.

Clement, C.R., and Reid, A.M., 1989, The origin of kimberlite pipes: an interpretation based on the synthesis of geological features displayed by South African occurrences: Proc. 4th Int. Kimberlite Conf., Perth Australia, Geol. Soc. Australia Spec. Publ., 14, p. 632-646.

Kurszlaukis, S., Franz, L., and Lorenz, V., 1998a, Volcanology of the Gibeon Kimberlite Field, southern Namibia: implications for the eruption mechanism of kimberlite pipes: Jl. Volcanol. Geotherm. Res., in press.

Kurszlaukis, S., Büttner, R., Zimanowski, B. and Lorenz, V., 1998b, On the first experimental phreatomagmatic explosion of a kimberlite melt: Jl. Volcanol. Geotherm. Res., in press.

Lorenz, V., 1975, Formation of phreatomagmatic maar-diatreme volcanoes and its relevance to the formation of kimberlite diatremes: Phys. Chem. Earth, 7, p. 17-27.

Lorenz, V., 1998, Zur Vulkanologie von diamantführenden Kimberlit- und Lamproit-Diatremen: Z. Dt. Gemmol. Ges., 47/1, p. 19-44.

Lorenz, V., and Kurszlaukis, S., 1997, On the last explosions of carbonatite pipe G3b, Namibia: Bull. Volcanol., 59, p. 1-9.

Lorenz, V., Zimanowski, B., and Fröhlich, J., 1994, Experiments on explosive basic and ultrabasic, ultramafic, and carbonatitic volcanism: In Meyer, H.O.A. and Leonardos, O.H. (eds.), Proc. 5th Int. Kimberlite Conf., Araxa, Brazil 1991, CPRM-Spec. Publ. 1, p. 270-282.

Nixon, P.H., 1995, The morphology and nature of primary diamondiferous occurrences: Jl. Geochem. Exploration, 53, p.41-71.

Zimanowski, B., Büttner, R., Lorenz, V., and Häfele, H.-G., 1997a, Fragmentation of basaltic melts in the course of explosive volcanism: Jl. Geophys. Res., 102, p.803-814.

Zimanowski, B., Büttner, R., and Lorenz, V., 1997b, Premixing of magma and water in MFCI experiments: Bull. Volcanol., 58, p. 491-495. 